\title{
The Adaptability of Cervical Cancer Patients
}

\author{
Yanti Hermayanti ${ }^{1}$, Heriandi Sutadi ${ }^{2}$, Setyowati Setyowati ${ }^{3}$, Sabarinah Sabarinah ${ }^{4}$ (D) Siti Ulfah Rifa'atul Fitri ${ }^{1}$ (D) \\ ${ }^{1}$ Department of Medical Surgical Nursing, Faculty of Nursing, Universitas Padjajaran, Bandung, Indonesia; ${ }^{2}$ Department \\ of Pediatric Dentistry, Faculty of Dentistry, Universitas Indonesia, Depok, Indonesia; ${ }^{3}$ Department of Maternity Nursing, \\ Faculty of Nursing, Universitas Indonesia, Depok, Indonesia; ${ }^{4}$ Department of Biostatistics, Faculty of Public Health, Universitas \\ Indonesia, Depok, Indonesia
}

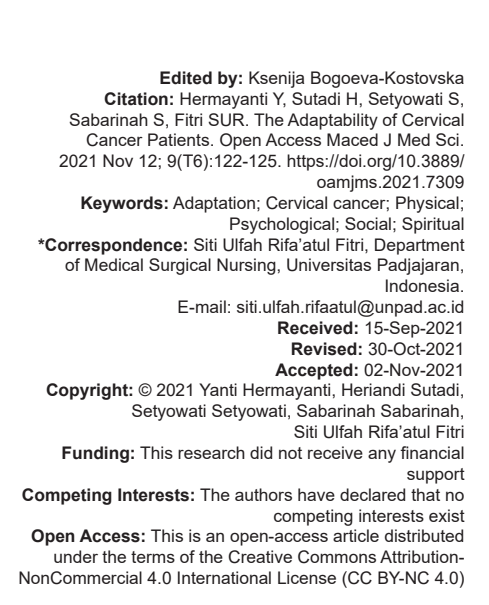

Abstract

BACKGROUND: The problems that arise in patients with cervical cancer are not only physical, but also include other aspects such as psychological, social, and spiritual. The ability of cervical cancer patients in dealing with these problems is very diverse and cannot be generalized.

AIM: The purpose of this study was to identify the adaptability of cervical cancer sufferers to physical, psychological social, and spiritual issues.

METHODS: A cross-sectional design study was conducted in this study. The number of samples was 96 respondents from a referral hospital in Bandung, West Java. The adaptability instrument was developed by researchers to assess physical, psychological, social, and spiritual adaptability. Statistical data analysis used univariate analysis for adaptive ability variable.

RESULTS: All components of adaptability were quite low, including general (14.6\%), physical (2.1\%), psychological $(19.7 \%)$, social $(27.1 \%)$, and spiritual $(27.1 \%)$.

CONCLUSION: Findings regarding factors that could affect the ability of adaptation are highly recommended. This is to determine the right type of intervention in helping adaptability of cervical cancer patients in various aspects so that patients can get the appropriate implementation from health workers.

\section{Introduction}

The most common cause of cervical cancer $(99 \%)$ is infection by the human papilloma virus (HPV). Furthermore, vaccines were found as a form of prevention, resulting in a drastic reduction in the incidence and death rate of cervical cancer, especially in some groups of developed countries. However, it is different from groups of developing countries where cases are still increasing, including in Indonesia. Based on data from GLOBOCAN, there were 18.1 million new cases with a death rate of 9.6 million, where 1 in 6 women in the world experience cancer and as many as 1 in 11 women die from cancer [1]. In 2018, the incidence of cervical cancer was second after breast cancer, reaching $9.3 \%$ with a mortality rate of $8.8 \%$ [2].

The problems that occur in cancer patients were not only in the physical aspect, but also often found in the psychological aspect. Initial responses that often arise were usually patients feeling sad, grieving, anxious, afraid, decreased self-image, low self-esteem and low self-perception, guilt, self-isolation, and depression [3], [4], [5], [6]. Most of the sufferers feel continuous loss and suffering [7], [8], [9], [10]. In addition to these problems, sufferers are also faced with physical problems due to the disease, such as pain in the lower abdomen, severe back pain, bleeding, odor, weight loss, fistulas, swollen feet, diarrhea, constipation, fever, cough, wounds, anemia and shortness of breath, damage to the skin mucosa, damage to healthy cells around cancer, nausea, and vomiting [11], [12], [13], [14].

In addition, they must also be prepared to face social impacts such as separation or loss of loved ones, having to forego routine activities usually carried out in their social environment [15], [16], [17]. Some of them must be prepared to accept the stigma that considers cancer to be a dirty disease [18], [19], [20]. For workers, they must accept having to possibly lose their job, which is a source of family income [16]. Patients also have to be ready to accept the possibility of death, so that a spiritual approach is needed [21]. All changes experienced need to be adapted by cancer patients so that they can still live a quality life.

Cervical cancer patients experience many changes, including physical, psychological, social and spiritual [5], [15]. This can hamper their daily activities so that it has an impact on decreasing the quality of life. Knowing the ability to adapt to a disease, especially in 
cervical cancer patients, will be useful data as an effort in developing nursing interventions related to improving the quality of life of patients, however, data on patient adaptability are still limited. This study aims to identify the adaptability of cervical cancer sufferers to the physical, psychological, social and spiritual changes that occur.

\section{Methods}

The researchers assess and identify the adaptability of cervical cancer patients using a crosssectional conducted at a referral hospital in Bandung, West Java with sample selected based on purposive sampling with certain criteria. The inclusion criteria of this study were: (1) able to communicate using Indonesian, verbally and non-verbally, (2) diagnosed with cervical cancer, (3) requiring hospitalization, (4) agreeing to be research respondents, (5) permanent residence. The number of samples was calculated based on the results of previous research [22], [23], [24]. To reduce classification bias, researchers selected respondents using the blinding method. Based on the results of previous research [22], [23], [24], the maximum sample size required in this study was 82 respondents; to anticipate the various possibilities the researcher added $10-20 \%$, so that the sample size needed in this study is 96 respondents.

The adaptability instrument was developed by researchers based on the results of a study of various measuring tools related to the assessment of various adaptability from various studies that have been carried out, including the quality of life instrument developed by the WHO [25]. Instrument modifications were made and adapted to the research objectives to assess adaptability in various aspects, including physical, psychological, social and spiritual. At the beginning of the preparation of the instrument, 32 simple closed questions were composed.

Based on a study conducted by experts on the questions asked, there were seven questions that did not meet the requirements, so that only 25 question items were revised and met the requirements to be used. The measuring scale used was a 5-point Likert scale The measurement results were used to determine the adaptive or maladaptive group for all abilities using the minimum adaptive value. The determination of the minimum assessment uses a standard benchmark value developed for various clinical abilities which have been employed in several previous research studies [26], [27], [28]. For adaptability, a minimum value of 75 or $60 \%$ was used, for physical adaptation a minimum value of 36 or $60 \%$, for psychological adaptation a minimum value of 12 or $60 \%$, for social adaptation a minimum value of 12 or $60 \%$, and for spiritual adaptation a minimum value of 15 or $60 \%$. This measuring tool has been tested on 30 respondents with Cronbach's alpha 0.901 . With this value, it was predicted that the measuring instrument will remain stable at different times with an inter-correlation value between items of more than 0.2 indicating that the measured factor or dimension is correct [29], [30].

Data processing was carried out using computer assistance after performing the stages of editing, coding, and tabulation in accordance with predetermined criteria. Frequency and percentage were used to describe the sample characteristic and adaptive ability variables. Data collection was carried out after the researcher obtained permission from various parties, including the research respondents.

\section{Results}

The results obtained were in the form of data on cervical cancer cases, namely: (1) The largest cervical cancer cases occurred in West Java [31], (2) Most of the cases $(70 \%)$ came to the hospital in an advanced stage [12], (3) The problems that occur in many patients were very complex, including physical, psychological, social and spiritual problems [32].

Table 1 shows the distribution of cervical cancer patients with more than $50 \%$ of the participants identified as being over 35 years of age with the latest level of education at the highest being junior high school. Most of them work as housewives with low economic status. For the advanced stage of cancer, it was obtained by more than $50 \%$ of participants. As for the type of therapy given, it was found that non-surgical therapy was dominant $(84.4 \%)$

Table 1: Distribution of cervical cancer patients with identifiable adaptability $(n=96)$

\begin{tabular}{lll}
\hline Variable & $\mathrm{N}$ & $\%$ \\
\hline Age (years) & 4 & \\
$\quad<35$ & 92 & 4.2 \\
$\quad 35$ & & 95.8 \\
Educational level & 77 & 80.2 \\
$\quad$ Junior High School & 19 & 19.8 \\
$\quad$ Senior High School & & \\
Employment status & 82 & 85.5 \\
$\quad$ A housewife & 14 & 14.5 \\
$\quad$ Self-employed & 13 & 13.5 \\
Financial level & 83 & 86.5 \\
$\quad$ High & 31 & 32.3 \\
$\quad$ Low & 65 & 67.7 \\
Staging of cancer & & \\
$\quad$ Early & 15 & 15.6 \\
$\quad$ Advanced & 81 & 84.4 \\
$\quad$ Type of treatment & & \\
$\quad$ Surgery & Non Surgery &
\end{tabular}

The results of observations showed that most of the patients' time was spent in the room for rest and sleep, the means to meet social and spiritual needs in the room were not available, and privacy was seen to be disturbed. Most of the sufferers looked sad, had empty eyes and were resigned to accept whatever happens 
to them. For some cases, they did not seem to have a life expectancy, but there was no indication of wanting to commit suicide. From the results of interviews with more than 30 patients and families on how to cope with the problems they face, the vast majority did not know the exact answer. They relied on belief without positive efforts [33].

The adaptive ability of the respondents can be seen in Table 2, wherein every aspect of the respondent's adaptive capacity was still quite low, including general, physical, psychological, social, and spiritual were below $50 \%$ as well.

Table 2: Adaptive ability of respondents $(n=96)$

\begin{tabular}{llllll}
\hline Components adaptive capabilities & \multicolumn{2}{l}{ Adaptive } & & \multicolumn{2}{c}{ Maladaptive } \\
\cline { 2 - 3 } & $\mathrm{n}$ & & $\mathrm{n}$ & & $\%$ \\
\hline General & 14 & & & 82 & 85.4 \\
Physical & 2 & 2.1 & & 94 & 97.9 \\
Psychological & 19 & 19.7 & & 77 & 80.3 \\
Social & 26 & 27.1 & & 70 & 72.9 \\
Spiritual & 26 & 27.1 & & 70 & 72.9 \\
\hline
\end{tabular}

\section{Discussion}

From the results of the data presented, it shows that the adaptive ability of the respondents is still lacking with the intervention that has been given by the nurses in the hospital. This is in accordance with [32] which states the burden faced by involving all aspects of life, both physically, psychologically, socially and spiritually, while efforts made or intervention provided more focused on disease management, because services at this time are more focused on handling physical illnesses only. Meanwhile, taking into consideration other aspects such as psychological, social, and spiritual is still lacking, even though these aspects are very influential in a person's integrity and will make the problem more complex. This condition has been criticized by the WHO [12] and by a number of other researchers, such as [13], [34], [35], [36], [37].

Adaptation, or adjustment, is being able to maintain existence, or being able to survive and obtain physical and spiritual wellbeing, and being able to establish satisfying relationships with social demands. If the ability to adapt is low, it can have an impact on physical, psychological, social and spiritual aspects which cannot be fulfilled optimally. Judging from the theory presented by Choirudin [38], the success of personal adjustment is marked by the absence of hatred, running away from reality or responsibility, resentment, disappointment, or disbelief in his condition; this is an example from a psychological point of view. Some of these circumstances can be prevented by careful planning of interventions to be administered to the patient. Nurses as medical workers who serve patients for 24 hours act as innovators and change agents to develop programs that can reduce the impact of a patient's inability to adapt.

\section{Conclusion}

The adaptability of cervical cancer sufferers is still lacking in several aspects. Therefore, appropriate intervention methods are needed so that the respondent can achieve maximum adaptive abilities in different aspects, considering psychological, social and spiritual in addition to the physical. It is recommended that nurses and other medical professionals provide an approach by paying attention to various aspects so that adaptation problems in patients can be resolved. It is also necessary to study what factors can affect adaptability so it can be determined what is the appropriate implementation for use.

\section{References}

1. GLOBOCAN. Global Cancer Facts and Figures. $2^{\text {nd }}$ ed. American Cancer Society Inc.; 2018.

2. Cancer Country Profile, Burden of Cancer; 2020. Available from: https://www.who.int/cancer/country-profiles/idn_2020.pdf?ua=1

3. Shinta D, Tamtomo G, Soemanto R. Factors affecting occurrence of depression in patients with cervical cancer at Dr. Moewardi Hospital Surakarta, Central Java: A path analysis model. J Epidemiol Public Health. 2019;4(4):338-50. https://doi. org/10.26911/jepublichealth.2019.04.04.09

4. Shyu IL, Hu LY, Chen YJ, Wang PH, Huang BS. Risk factors for developing depression in women with cervical cancer: A nationwide population-based study in Taiwan. Int J Womens Health. Int J Womens Health. 2019;11:135-41. https://doi. org/10.2147/ijwh.s193003 PMid:30804687

5. Yaman S, Ayaz S. Psychological problems experienced by women with gynecological cancer and how they cope with it: A phenomenological study in Turkey. Health Soc Work. 2016;41(3):173-81. https://doi.org/10.1093/hsw/hlw030 PMid:29206956

6. Hamid A. Bunga Rampai Asuhan Keperawatan Kesehatan Jiwa. Jakarta: EGC; 2009.

7. Bosire A, Mageto I, Kimni S. Psychological effects of chemotherapy experienced by patients diagnosed with breast and cervical cancer attending kenyatta national hospital cancer treatment centre. Int J Health Sci Res. 2020;10(1):166-174. Available from: https://www.jihsr.org/ijhsr_vol.10_issue.1_ jan2020/27.pdf

8. Roos S. Chronic Sorrow a Living Los. New York: BrunnerRoutledge; 2002

9. Peterson SJ, Bredow TS, editors. Middle range theories: Application to nursing research. Lippincott Williams \& Wilkins: 2009.

10. Livneh H, Martz E, editors. Coping with Chronic Illness and Disability: Theoretical, Empirical, and Clinical Aspects. Springer; 2007.

11. Imelda F, Darti NA, Siregar FL. Effect of physical exercise on fatigue in cervical cancer patients. Inones J Nurs Midwifery. 2019;7(1):41-6. Available from: https://doi.org/10.21927/jnki.2019.7(1).41-46

12. World Health Organization. Cervical Cancer and the Human Papilloma Virus (HPV). Geneva: World Health Organization; 
2010. Available from: http://www.who.int/reproductivehealth/ topics/cancer/en. [Last accessed on 2021 May 18].

13. Brown, et al. Gynaecological Cancer Guidance for Nursing Staff. London: The Royal College of Nursing; 2005.

14. Sjamsuhidajat $R$, de Jong W. Buku Ajar IImu Bedah Cet. $2^{\text {nd }}$ ed. Jakarta: EGC; 2004.

15. Tadese SK. Socio-economic and cultural vulnerabilities to cervical cancer and challenges faced by patients attending care at Tikur Anbessa Hospital: A cross sectional and qualitative study. BMC Womens Health. 2015;15:75. https://doi. org/10.1186/s12905-015-0231-0 PMid:26376638

16. Foster C, Wright D, Hill H, Hopkinson J, Roffe L. Psychosocial implications of living 5 years or more following a cancer diagnosis: A systematic review of the research evidence. Eur J Cancer Care (Engl). 2009;18(3):223-47. https://doi. org/10.1111/j.1365-2354.2008.01001.x PMid:19432917

17. van Weert E, Hoekstra-Weebers JE, Grol BM, Otter R, Arendzen JH, Postema K, et al. Physical functioning and quality of life aftercancer rehabilitation. Int J Rehabil Res. 2004;27(1):27-35. https://doi.org/10.1097/00004356-200403000-00004 PMid:15097167

18. Nyblade L, Stockon M, Travaso S, Krishan S. A qualitative exploration of cervical and breast cancer stigma in Karnataka India. BMC Womens Health. 2017;17(1):58. https://doi. org/10.1186/s12905-017-0407-x

PMid:28768506

19. Mays RM, Zimet GD, Winston Y, Kee R, Dickes J, Su L. Human papillomavirus, genital warts, pap smears, and cervical cancer: Knowledge and beliefs of adolescent and adult women. Health Care Women Int. 2000;21(5):361-74. https://doi. org/10.1080/07399330050082218 PMid:11261107

20. Mills N, Daker-White G, Graham A, Campbell R. Population screening for Chlamydia trachomatis infection in the UK: A qualitative study of the experiences of those screened. Fam Pract. 2006;23(5):550-7. https://doi.org/10.1093/fampra/cml031 PMid: 16790452

21. van Dyk A, Small $L$, Zietsman $A$. The pain experience and its management in cancer patients during hospitalization. Health SA. 2000;5(4):1437-49. https://doi.org/10.4102/hsag. v5i4.41

22. Taylor EJ. Prevalence and associated factors of spiritual needs among patients with cancer and family caregivers. Oncol Nurs Forum. 2006;33(4):729-35. https://doi.org/10.1188/06. onf.729-735 PMid:16858453

23. Yanti A, Andrijono A, Gayatri G. Perubahan keluhan seksual (fisik dan psikologis) pada perempuan pascaterapi kanker serviks setelah intervensi keperawatan. J Ners. 2011;6(1):68-75.
24. Howren MB, Christensen AJ, Karnell LH, Funk GF. Healthrelated quality of life in head and neck cancer survivors: Impact of pretreatment depressive symptoms. Health Psychol. 2010;29(1):65-71. https://doi.org/10.1037/a0017788 PMid:20063937

25. Kim S. World Health Organization quality of life (WHOQOL) assessment. In: Michalos AC, editor. Encyclopedia of Quality of Life and Well-Being Research. Dordrecht, Netherlands: Springer; 2014. p. 7260-1. https://doi. org/10.1007/978-94-007-0753-5_3282

26. Martin I, Jolly B. Predictive validity and estimated cut score of an objective structured clinical examination (OSCE) used as an assessment of clinical skills at the end of the first clinical year. Med Educ. 2002;36(5):418-25. https://doi. org/10.1046/j.1365-2923.2002.01207.x PMid:12028391

27. Newble D. Techniques for measuring clinical competence: Objective structured clinical examinations. Med Educ. 2004;38(2):199-203. https://doi. org/10.1111/j.1365-2923.2004.01755.x PMid: 14871390

28. Varkey P, Natt N, Lesnick T, Downing S, Yudkowsky R. Validity evidence for an OSCE to assess competency in systemsbased practice and practice-based learning and improvement: A preliminary investigation. Acad Med. 2008;83(8):775-80. https://doi.org/10.1097/acm.0b013e31817ec873 PMid: 18667895

29. Burns R, Burns R. Business Research Methods and Statistics Using SPSS. London: SAGE Publications, Inc.; 2008.

30. Henerson ME, Morris LL, Fitz-Gibbon CT. How to Measure Attitudes. California: SAGE Publication Inc.; 1988.

31. LPKI, Indonesia. Penyuluhan Kesehatan Penyakit Kanker, Bandung; 2010.

32. Hermayanti Y. Nursing Care Needs Advanced Stage of Cervical Cancer. The Proceeding of International Conference: Health and the Changing World, 2008; 2012.

33. Hermayanti $Y$. The quality of nursing care services for cervical cancer patient in West Java. In: Bringing Current Research into Nursing Practice for Improving Quality of Care; 2012.

34. Manuaba I. Kapita Selekta Penatalaksanaan Rutin Obstetri Ginekologi dan KB. Jakarta: EGC; 2001.

35. Mishra S, Bhatnagar S, Singhal AK. Recent trends in cancer pain management. Indian J Med Paediatr Oncol. 2004;25(4):22-8.

36. Yatim F. Penyakit Kandungan Myom, Kista, Indung Telur, Kanker Rahim/Leher Rahim, Serta Gangguan Lainnya. Jakarta: Pustaka Populer Obor; 2005.

37. EGC. Syafrudin and Hamidah, Kebidanan Komunitas. Jakarta: EGC; 2009.

38. Choirudin M. Penyesuaian Diri: Sebagai Upaya Mencapa Kesejahteraan Jiwa; 2015. https://doi.org/10.14421/ hisbah.2015.121-07 